\title{
The effect of environmental parameters and cyanobacterial blooms on phytoplankton dynamics of a Portuguese temperate lake
}

\author{
Daniela R. de Figueiredo ${ }^{1, *}$, Ana S.S.P. Reboleira ${ }^{1}$, Sara C. Antunes ${ }^{1}$, Nelson Abrantes ${ }^{1}$, \\ Ulisses Azeiteiro ${ }^{2}$, Fernando Gonçalves ${ }^{1} \&$ Mário J. Pereira ${ }^{1}$ \\ ${ }^{1}$ Department of Biology, University of Aveiro, 3810-193 Aveiro, Portugal \\ ${ }^{2}$ IMAR - Institute of Marine Research, Universidade de Coimbra, 3004-517 Coimbra, Portugal \\ (*Author for correspondence: E-mail: dfigueiredo@bio.ua.pt)
}

Received 9 January 2006; in revised form 1 February 2006; accepted 7 February 2006; published online 5 May 2006

Key words: eutrophic lake, phytoplankton dynamics, environmental parameters, Aphanizomenon flos-aquae, Microcystis aeruginosa, multivariate analysis

\begin{abstract}
The increasing occurrence of cyanobacterial blooms in freshwaters is of great concern due to the ability of many cyanobacteria to produce cyanotoxins. In the present work, the eutrophied Vela Lake (Central Portugal), used for recreational purposes and as a water source for agriculture, was monitored every fortnight between 2000 and 2001. Phytoplankton diversity and densities were measured and correlated to environmental parameters. A seasonal phytoplanktonic succession was observed and it was mainly correlated with conductivity, temperature, total suspended solids and nutrients availability (particularly phosphorus). Diatoms were dominant during winter months (inferior temperatures and higher nutrients availability) followed by green algae in early spring and then cyanobacteria from late spring until early autumn (less nutrient availability and higher temperatures). A massive cyanobacterial bloom of Aphanizomenon flos-aquae occurred early in May 2001 and was preceded by the lowest nitrogen levels measured in the water during all the study period. At the time of this bloom senescence, dissolved oxygen was severely depleted and a massive death of ichthyofauna was recorded. A Microcystis aeruginosa bloom was also detected in July 2001 and it occurred following a rapid decrease in abundance of green algae and diatoms. By considering not only the environmental parameters but also the occurrence of cyanobacterial blooms as explanatory variables in a canonical correspondence analysis, the variance explained for the phytoplanktonic assemblage during the study period was increased in about $7 \%$ achieving a total of $61.0 \%$, indicating a correlation that may be due to the known competitive advantage and/or allelopathy of the bloom-forming cyanobacteria towards microalgae.
\end{abstract}

\section{Introduction}

Eutrophication of surficial freshwaters is increasing worldwide mainly due to the pressure of anthropogenic activities on aquatic systems which are related to nutrient inputs from agriculture, livestock production, urbanization and industry (Codd, 2000). The low TN:TP ratios, along with thermal stratification, reduced transparency and an increase in water temperature and $\mathrm{pH}$, frequently enhance the occurrence of cyanobacterial blooms (Dokulil \& Teubner, 2000; Jacoby et al.,
2000; Oliver \& Ganf, 2000; Chellappa \& Costa, 2003; Mischke, 2003). The primary consequence of bloom occurrence is the water quality reduction, which can lead to negative economical, ecological and public health implications (Codd, 2000). From an ecological point of view, declines in specific biodiversity occur at all trophic levels and there is a deterioration of the habitat, with increased turbidity and a decrease in oxygen concentration. There is also the production of substances that give a bad taste and odour to the water, along with the fact that blooms of cyanobacteria may become 
dangerous due to the ability of many cyanobacterial strains to produce toxins that can affect a variety of organisms, including humans (Pouria et al., 1998; Codd, 2000; WHO, 2003; de Figueiredo et al., 2004a). Presently, there are more than 50 known toxic cyanobacterial species mainly belonging to the genera Microcystis, Planktothrix, Anabaena, Oscillatoria, Aphanizomenon, Lyngbya, Cylindrospermopsis, Synechococcus, Gloeotrichia, Nostoc, Schizothrix, Synechocystis and Nodularia (Chorus \& Bartram, 1999).

Toxic cyanobacterial blooms have already been reported in many Portuguese water bodies (Vasconcelos, 2001). The water body studied in the present work was Vela Lake (Figueira da Foz, Portugal), a shallow eutrophied freshwater body used for recreational purposes and as a water source for agriculture. There are not many published studies about this lake (Antunes et al., 2003) in spite of being subject to investigation at different levels during the last decade, particularly with regard to the occurrence of toxic cyanobacterial blooms (Vasconcelos et al., 1993). More than 40 Microcystis aeruginosa strains isolated from Vela Lake have been reported as toxic (Vasconcelos et al., 1993). Toxic strains of Aphanizomenon flosaquae occur in Portuguese freshwater reservoirs (Pereira et al., 2000; Ferreira et al., 2001) and also in lakes such as the shallow Mira Lake, in centralwestern Portugal (Vasconcelos, 1999). Both these species have been shown to cause inhibitory effects over the development of phytoplankton (Singh et al., 2001; de Figueiredo et al., 2004b; Suikkanen et al., 2004) and zooplankton (Lotocka, 2001; de Figueiredo et al., 2004c). In the present work, during an annual cycle (2000/2001), the phytoplankton composition and dynamics in Vela Lake were monitored and related to environmental parameters as well as the occurrence of cyanobacterial blooms through canonical multivariate analysis.

\section{Materials and methods}

Study area and sampling

Vela Lake $\left(44^{\circ} 58^{\prime} \mathrm{N}, 5^{\circ} 18^{\prime} \mathrm{W}\right)$ is a shallow eutrophied freshwater body located in Quiaios (Figueira da Foz, Central Portugal). It has an area of approximately 70 ha and is $6 \mathrm{~km}$ away from the Atlantic Ocean. The lake is surrounded by Pinus spp., sandy soil and agricultural areas. The water volume is predominantly influenced by the variation of groundwater levels and rainfall, which makes the lake very susceptible to drought during summer months (Silva et al., 1997). This water body is used for recreation and agricultural purposes. The organic matter and nutrient inputs come mainly from human activities (such as agriculture and modification of land) in surrounding areas. Antunes et al. (2003) has reported an increase of the nutrient levels during the last decade. The municipal removal of groundwater has been also reported as a threat to the future conservation of Vela Lake (Silva et al., 1997). Water samples were collected just below the water surface and included three replicates of 11 sampled in neighbouring sites for environmental parameters and phytoplankton analyses. The samples were taken every fortnight during an annual cycle (from November 2000 to November 2001) always in the same sites and in the morning.

\section{Environmental parameters and chlorophyll a}

Water temperature, conductivity, $\mathrm{pH}$ and dissolved oxygen were determined in situ using portable water testing meters (WTW LF 330 conductivity meter, WTW 340-A pH meter and WTW OXI 320 oxygen meter). In the laboratory, the total suspended solids (TSS), soluble reactive phosphorus (SRP), chlorophyll $a$ (Chl $a$ ), ammonium, nitrate and nitrite concentrations were determined according to methodologies described by Lind (1979) and APHA (1992).

\section{Phytoplankton analysis}

Qualitative phytoplankton samples were collected using a net with $25 \mu \mathrm{m}$ mesh size and fixed in phormol $(5 \% \mathrm{v} / \mathrm{v})$ for species identification, which was made by observation under a light microscope and through Scanning Electron Microscopy (SEM). Identification of the main phytoplanktonic groups were made with reference to: Cyanoprokaryota (Geitler, 1932; Komárek \& Anagnostidis, 1989, 1999), Bacillariophyceae (Germain, 1981; Krammer \& Lange-Bertalot, 
1986-1991; Lange-Bertalot, 2001) and Chlorococcales (Komárek \& Fott, 1983). For the quantification of phytoplankton, samples were fixed in Lugol's solution ( $1 \% \mathrm{v} / \mathrm{v})$ and the enumeration was performed according to Lund et al. (1958).

\section{Statistical analysis}

The results obtained during the study period for the environmental variables and the species composition of phytoplankton were subjected to a CCA (canonical correspondence analysis) (ter Braak, 1986, 1995) to examine relationships between them. Before running the analysis, the environmental data (including the A. flos-aquae and $M$. aeruginosa densities which were used in the second CCA analysis as explanatory variables due to their toxic potential) were standardized (by subtracting the mean from each observation and dividing by the corresponding standard deviation) and the phytoplankton abundances were logarithmically transformed. In order to determine the variables best related to the phytoplankton dynamics during the one-year study, a Monte Carlo permutation test was applied.

\section{Results}

\section{Environmental parameters and chlorophyll a}

Environmental parameters are all summarized in Table 1. During the study period (from November 2000 to November 2001), the water temperature ranged from 10.3 to $29.4{ }^{\circ} \mathrm{C}$ with the highest temperatures recorded in June and the lowest in November. In spite of the high variation of dissolved oxygen levels, especially in summer, oxygen was at moderate concentrations all year (between 5.10 and $13.30 \mathrm{mg} \mathrm{l}^{-1}$ ), except for the end of May, when it was below the detection level $\left(0.01 \mathrm{mg} \mathrm{l}^{-1}\right)$. The $\mathrm{pH}$ ranged from 7.29 to 8.34 during winter but tended to increase during the warmer months (between 8.72 and 9.94). Conductivity had the highest values between November 2000 and January 2001 (with a maximum of $493 \mu \mathrm{S} \mathrm{cm}^{-1}$ ) and ranged between 272 and $370 \mu \mathrm{S} \mathrm{cm}^{-1}$ during the rest of the year. Total suspended solids showed increased values from June until November $2001\left(>0.028 \mathrm{~g} \mathrm{l}^{-1}\right)$, with the highest value $\left(0.081 \mathrm{~g} \mathrm{l}^{-1}\right)$ observed in the latter half of July. Chlorophyll a concentrations oscillated many times during the one-year study with the highest value $\left(149.43 \mathrm{mg} \mathrm{m}^{-3}\right)$ in the middle of May, coinciding with a dense cyanobacterial bloom in the lake.

Concentrations of SRP and nitrogen sources (nitrate, nitrite and ammonium) reached the highest levels in late December 2000 and early January 2001 (Table 1). Dissolved inorganic nitrogen levels were higher in winter and lower in spring, summer and autumn. The annual range of nitrate concentration was $0.3-6.6 \mathrm{mg} \mathrm{NO}_{3}-\mathrm{N}^{-1}$ with the highest values in winter and the lowest in late spring. The highest nitrite concentration was $0.205 \mathrm{mg} \mathrm{NO}_{2}$ $\mathrm{N}^{-1}$ in late December 2000 and nitrite was generally undetectable from April to November 2001. Ammonium levels were generally low throughout the year, with values between 0.35 and $0.85 \mathrm{mg} \mathrm{NH} \mathrm{NH}_{4}-\mathrm{N}^{-1}$. However, high levels were recorded between November and December 2000, ranging from 1.53 to $2.19 \mathrm{mg} \mathrm{NH} \mathrm{NH} \mathrm{l}_{4}^{-1}$. A sudden increase was recorded at the end of May 2001 (up to $1.8 \mathrm{mg} \mathrm{NH}_{4}-\mathrm{N}^{-1}$ ). Soluble reactive phosphorus was detected only between November 2000 and June 2001, with a maximum of $1.65 \mathrm{mg} \mathrm{l}^{-1}$ in December and with depletion of this nutrient during the remaining months of the study period.

\section{Phytoplankton composition}

During the study period, 245 algal taxa were identified in Vela Lake: 144 Bacillariophyceae, 56 Chlorophyta, 24 Euglenophyta, 10 for Cyanobacteria and 11 for other groups such as Chrysophyceae, Dinophyta and Xanthophyceae. The most abundant taxa are presented in Table 2 and their annual variation is presented in Figure 1a.

Diatoms dominated from November 2000 to early March 2001 (with densities between $7.81 \times 10^{4}$ and $1.32 \times 10^{6}$ cells ml ${ }^{-1}$ ) (Fig. 1b), coinciding with elevated conductivity levels $\left(327-493 \mu \mathrm{S} \mathrm{cm}^{-1}\right)$ and low values for temperature $\left(11.5-16.6^{\circ} \mathrm{C}\right)$ and $\mathrm{pH}$ (7.29-8.34). During this period, the TSS concentration was also relatively low $\left(0.002-0.030 \mathrm{~g} \mathrm{l}^{-1}\right)$ and the nutrient (DIN and SRP) concentrations were high (2.23-7.30 $\mathrm{mg}^{-1}$ for DIN and 0.53$1.65 \mathrm{mg} \mathrm{l}^{-1}$ for SRP). The highest levels of nutrient concentrations preceded a small bloom of diatoms (up to a density of $1.32 \times 10^{6}$ cells ml $^{-1}$ ) at the 
Table 1. Environmental data recorded during the one-year study period (from November 2000 to November 2001) in Vela Lake

\begin{tabular}{|c|c|c|c|c|c|c|c|c|c|c|c|}
\hline & $\begin{array}{l}\text { Dissolved } \\
\text { oxygen } \\
\left(\mathrm{mg} \mathrm{l}^{-1}\right)\end{array}$ & $\begin{array}{l}\text { Chl } a \\
\left(\mathrm{mg} \mathrm{m}^{-3}\right)\end{array}$ & $\begin{array}{l}\text { TSS } \\
\left(\mathrm{g} \mathrm{l}^{-1}\right)\end{array}$ & $\begin{array}{l}\text { Temp. } \\
\left({ }^{\circ} \mathrm{C}\right)\end{array}$ & $\mathrm{pH}$ & $\begin{array}{l}\mathrm{NO}_{2}-\mathrm{N} \\
\left(\mathrm{mg} \mathrm{l}^{-1}\right)\end{array}$ & $\begin{array}{l}\mathrm{NO}_{3}-\mathrm{N} \\
\left(\mathrm{mg} \mathrm{l}^{-1}\right)\end{array}$ & $\begin{array}{l}\mathrm{NH}_{4}-\mathrm{N} \\
\left(\mathrm{mg} \mathrm{l}^{-1}\right)\end{array}$ & $\begin{array}{l}\text { DIN } \\
\left(\mathrm{mg} \mathrm{l}^{-1}\right)\end{array}$ & $\begin{array}{l}\text { SRP } \\
\left(\mathrm{mg} \mathrm{l}^{-1}\right)\end{array}$ & $\begin{array}{l}\text { Conductivity } \\
\left(\mu \mathrm{S} \mathrm{cm}^{-1}\right)\end{array}$ \\
\hline November & 5.10 & 29.61 & 0.026 & 12.2 & 7.52 & 0.003 & 0.7 & 1.53 & 2.2 & 0.53 & 493 \\
\hline \multirow[t]{2}{*}{ December } & 7.23 & 30.75 & 0.030 & 14.6 & 7.61 & 0.064 & 2.8 & 2.19 & 5.1 & 0.75 & 475 \\
\hline & 7.61 & 14.98 & 0.011 & 11.9 & 7.70 & 0.205 & 4.8 & 1.64 & 6.6 & 1.65 & 452 \\
\hline \multirow[t]{2}{*}{ January } & 7.54 & 21.74 & 0.015 & 12.7 & 7.77 & 0.086 & 6.6 & 0.61 & 7.3 & 1.06 & 419 \\
\hline & 7.84 & 38.80 & 0.020 & 11.5 & 8.34 & 0.009 & 4.7 & 0.48 & 5.2 & 1.22 & 372 \\
\hline \multirow[t]{2}{*}{ February } & 7.42 & 7.65 & 0.004 & 12.3 & 7.29 & 0.026 & 4.4 & 0.45 & 4.9 & 1.27 & 346 \\
\hline & 7.00 & 2.14 & 0.002 & 16.6 & 7.35 & 0.038 & 3.6 & 0.52 & 4.2 & 1.27 & 327 \\
\hline \multirow[t]{3}{*}{ March } & 9.00 & 13.86 & 0.010 & 14.5 & 8.06 & 0.032 & 2.8 & 0.48 & 3.3 & 0.93 & 331 \\
\hline & 7.80 & 10.18 & 0.006 & 15.1 & 7.76 & 0.042 & 2.6 & 0.50 & 3.1 & 1.01 & 335 \\
\hline & 11.70 & 33.64 & 0.006 & 15.3 & 8.72 & 0.023 & 1.8 & 0.35 & 2.2 & 0.67 & 327 \\
\hline \multirow[t]{2}{*}{ April } & 9.90 & 22.61 & 0.012 & 19.0 & 9.40 & 0 & 0.5 & 0.36 & 0.9 & 0.16 & 341 \\
\hline & 10.20 & 29.90 & 0.016 & 15.2 & 8.52 & 0 & 0.3 & 0.36 & 0.7 & 0.19 & 364 \\
\hline \multirow[t]{2}{*}{ May } & 10.00 & 149.40 & 0.028 & 17.5 & 8.95 & 0 & 0.5 & 0.85 & 1.4 & 0.24 & 348 \\
\hline & 0 & 19.22 & 0.023 & 28.7 & 8.24 & 0.010 & 0.6 & 1.81 & 2.4 & 0.24 & 315 \\
\hline \multirow[t]{2}{*}{ June } & 8.70 & 66.93 & 0.028 & 23.4 & 9.25 & 0 & 0.6 & 0.46 & 1.1 & 0 & 306 \\
\hline & 13.30 & 28.48 & 0.053 & 29.4 & 9.94 & 0 & 0.8 & 0.54 & 1.3 & 0 & 289 \\
\hline \multirow[t]{2}{*}{ July } & 11.50 & 65.27 & 0.081 & 23.5 & 9.60 & 0 & 1.1 & 0.84 & 1.9 & 0 & 297 \\
\hline & 6.10 & 54.51 & 0.070 & 24.9 & 8.84 & 0 & 1.0 & 0.65 & 1.7 & 0 & 272 \\
\hline August & 10.90 & 27.65 & 0.055 & 26.4 & 9.49 & 0 & 0.8 & 0.64 & 1.4 & 0 & 298 \\
\hline \multirow[t]{2}{*}{ September } & 9.80 & 42.10 & 0.060 & 23.8 & 8.82 & 0 & 0.4 & 0.47 & 0.9 & 0 & 310 \\
\hline & 9.80 & 44.50 & 0.071 & 18.6 & 9.04 & 0 & 0.6 & 0.58 & 1.2 & 0 & 300 \\
\hline \multirow[t]{2}{*}{ October } & 8.60 & 21.36 & 0.055 & 17.9 & 8.90 & 0 & 0.5 & 0.52 & 1.0 & 0 & 299 \\
\hline & 11.90 & 24.72 & 0.043 & 17.0 & 9.40 & 0 & 0.6 & 0.49 & 1.1 & 0 & 305 \\
\hline \multirow[t]{2}{*}{ November } & 10.60 & 36.12 & 0.049 & 12.0 & 9.01 & 0 & 0.6 & 0.56 & 1.2 & 0 & 346 \\
\hline & 10.33 & 13.86 & 0.042 & 10.3 & 8.98 & 0 & 0.5 & 0.49 & 1.0 & 0 & 370 \\
\hline
\end{tabular}

beginning of January dominated by Aulacoseira granulata var. angustissima. Other identified Bacillariophyceae taxa that showed high densities during this year included Aulacoseira ambigua, A. granulata and Stephanodiscus (Cyclostephanus) invisitatus (Fig. 2a).

Chlorophytes were generally dominant in late March and April (reaching cell densities between 0.78 and $1.30 \times 10^{6}$ cells $\mathrm{ml}^{-1}$ ). This correlated with the decrease in nutrient levels and conductivity and rising temperature and $\mathrm{pH}$ (Table 1). The dominant taxa included Coelastrum reticulatum var. reticulatum, Kirchneriella lunaris, Monoraphidium contortum, Scenedesmus acuminatus var. acuminatus and Pediastrum boryanum var. boryanum. Nevertheless, the Chlorophyta community was relatively stable from January until November (Fig. 2b), except in July (at the time of the
$M$. aeruginosa bloom) when its abundance decreased. During the senescence of the A. flos-aquae bloom (coinciding with severe oxygen depletion and an increase in ammonium levels), at the end of May, the changes in chlorophyta taxa included the decrease of Coelastrum reticulatum var. reticulatum and an increase in Monoraphidium contortum abundance (attaining its highest levels) and the isolated appearance of Kirchneriella lunaris (Fig. 2b).

Cyanobacteria dominated from May until November 2001 with densities ranging from $4.66 \times 10^{5}$ to $4.58 \times 10^{7}$ cells $\mathrm{ml}^{-1}$. This cyanobacterial dominance corresponded to the lowest nutrient values (0.660-2.420 $\mathrm{mg} \mathrm{l}^{-1}$ for DIN and 0-0.24 $\mathrm{mg}^{-1}$ for $\mathrm{SRP})$ as well as the lowest conductivity recorded $\left(272-370 \mu \mathrm{S} \mathrm{cm}^{-1}\right)$. In contrast, the highest values for temperature (15.2-29.4 $\left.{ }^{\circ} \mathrm{C}\right), \mathrm{pH}(8.24-9.94)$ and 
Table 2. Most abundant algal taxa recorded for Vela Lake during the study period (from November 2000 to November 2001). The four letter words were used as species labels in the multivariate analysis

\begin{tabular}{|c|c|}
\hline \multicolumn{2}{|l|}{ Cyanobacteria } \\
\hline Aphanizomenon flos-aquae (L.) Ralfs & APHA \\
\hline Chroococcus limneticus Lemmermann & CHRL \\
\hline Microcystis aeruginosa (Kützing) Kützing & MIAE \\
\hline Oscillatoria sp. & OSCL \\
\hline Pseudanabaena sp. & PSDA \\
\hline \multicolumn{2}{|l|}{ Bacillariophyceae } \\
\hline Achnanthes minutissima Kützing & ACHM \\
\hline Amphora lybica Ehrenberg & AMPL \\
\hline Amphora ovalis (Kützing) Kützing & AMPO \\
\hline Aulacoseira ambigua (Grunow) Simonsen & AULA \\
\hline Aulacoseira granulata (Ehrenberg) Simonsen & AULG \\
\hline Aulacoseira granulata (Ehrenberg) & AUGA \\
\hline \multicolumn{2}{|c|}{ Simonsen var. angustissima (O. Müller) Simonsen } \\
\hline Cocconeis placentula Ehrenberg & $\mathrm{COCP}$ \\
\hline Craticula cuspidata (Kützing) Mann & CRTC \\
\hline Craticula halophila (Grunow & CRTH \\
\hline \multicolumn{2}{|l|}{ ex Van Heurck) Mann } \\
\hline Cyclotella ocellata Pantocsek & $\mathrm{CYCO}$ \\
\hline Cyclotella meneghiniana Kützing & $\mathrm{CYCM}$ \\
\hline Cyclotella radiosa (Grunow) Lemmermann & CYCR \\
\hline Cyclotella stelligera $($ Cleve & CYCS \\
\hline \multicolumn{2}{|l|}{ \& Grunow) Van Heurck } \\
\hline Cymbella helvetica Kützing & $\mathrm{CYMH}$ \\
\hline Cymbella ventricosa C. Agardh & CYMV \\
\hline Denticula tenuis Kützing & DENT \\
\hline Diploneis ovalis (Hilse) Cleve & DPLO \\
\hline Epithemia adnata (Kützing) Brébisson & EPTA \\
\hline Eunotia pectinalis (Dyllwyn) Rabenhorst & EUNP \\
\hline Fragilaria brevistriata Grunow & FRGB \\
\hline Fragilaria capucina Desmazières & FRCP \\
\hline Fragilaria construens (Ehrenberg) Grunow & FRCT \\
\hline Fragilaria crotonensis Kitton & FRCR \\
\hline Fragilaria leptostauron (Ehrenberg) Hustedt & FRGL \\
\hline Fragilaria pinnata Ehrenberg & FRGP \\
\hline Fragilaria ulna (Nitzsch) Lange-Bertalot & FRGU \\
\hline Gomphonema clevei Fricke & GPHS \\
\hline Gomphonema augur Ehrenberg & GPAU \\
\hline Gomphonema affine Kützing & GPAF \\
\hline Gomphonema gracile Ehrenberg & GPGR \\
\hline Gomphonema parvulum Kützing & GPPV \\
\hline Gomphonema pumilum (Grunow) & GPPM \\
\hline Reichardt \& Lange-Bertalot & \\
\hline
\end{tabular}

Table 2. (Continued)

\begin{tabular}{ll}
\hline Gomphonema truncatum Ehrenberg & GPTR \\
Mastogloia smithii Thwaites ex W. Smith & MSTS \\
Melosira varians Agardh & MELV \\
Navicula capitata Ehrenberg var. & NVCP \\
hungarica (Grunow) Ross & \\
Navicula oligotraphenta & NVOL
\end{tabular}

Lange-Bertalot \& Hofmann

Navicula radiosa Kützing

Neidium dubium (Ehrenberg) Cleve

NVRD

NDDB

NTZP

PNMR

PLCN

RHPG

STIV

Cyclostephanos invisitatus (Hohn \&

SURA

Sellaphora pupula (Kützing) Mereschkowksy

Chlorophyta

Botryococcus braunii Kützing

Coelastrum reticulatum

BTRB

COEL

(Dangeard) Senn var. reticulatum

Kirchneriella lunaris (Kirchner) Moebius

$\mathrm{KRCH}$

Lagerheimia subsalsa Lemmermann

LGRH

Monoraphidium contortum

MNRC

(Thuret) Komárkova-Legnerová

Pediastrum boryanum

PDBR

(Turpin) Meneghini var. boryanum

Pediastrum duplex Meyen var. duplex

Pediastrum simplex Meyen var. simplex

Pediastrum simplex Meyen

var. echinulatum Wittrock

Pediastrum tetras (Ehrenberg) Ralfs

Scenedesmus acuminatus

(Lagerheim) Chodat var. acuminatus

Scenedesmus acutus (Meyen) Chodat var. acutus

Scenedesmus gutwinskii Chodat var. heterospina

Scenedesmus oahuensis

(Lemmermann) G.M. Smith

Scenedesmus opoliensis

P. Richter var. monoensis Chodat

Scenedesmus protuberans Fritsch

Scenedesmus semicristatus Uherkowich

Scenedesmus serratus (Corda) Bohlin

Scenedesmus spinosus Chodat

Tetraedron caudatum (Corda) Hansgirg

Tetraedron minimum (A. Braun) Hansgirg 

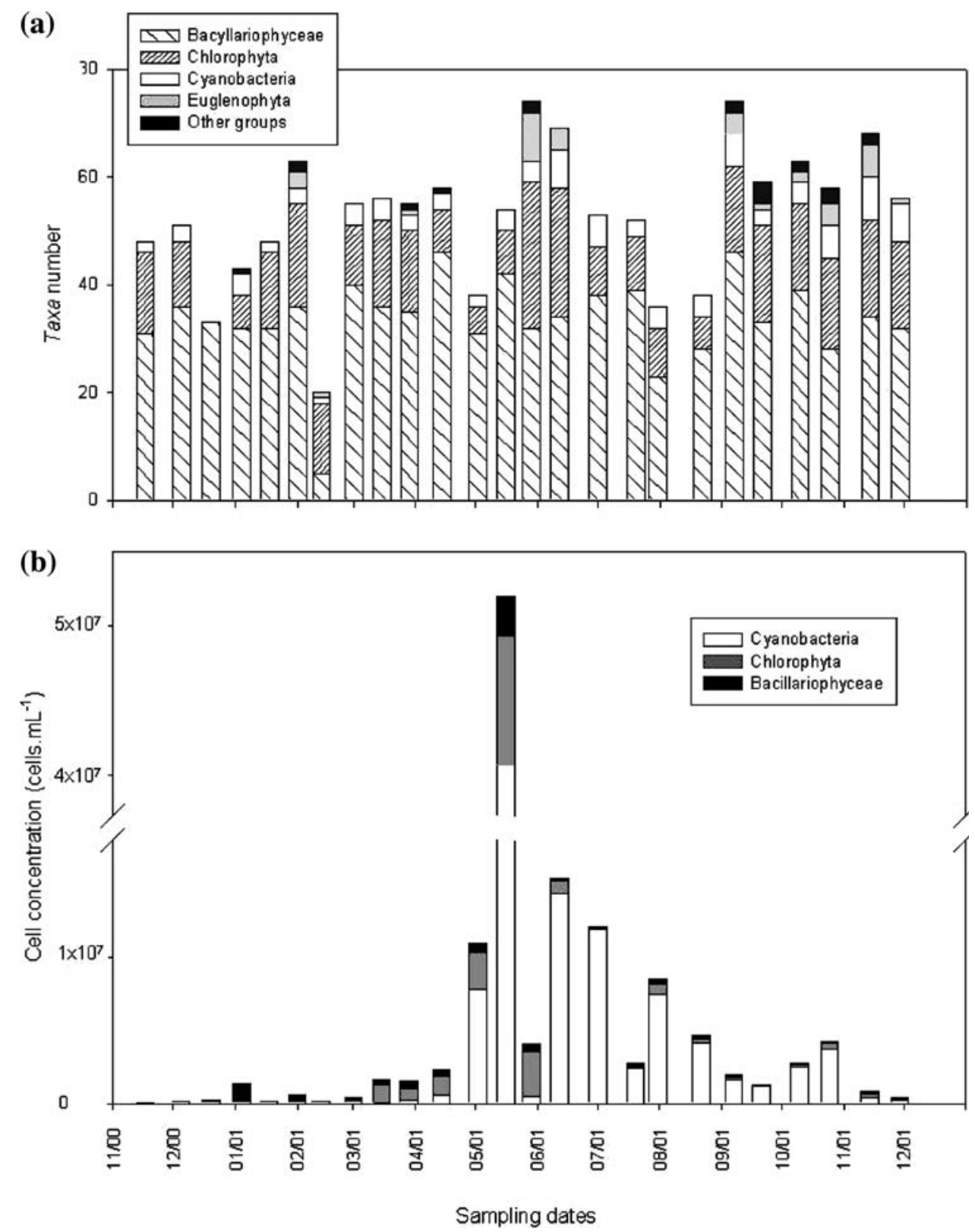

Figure 1. Seasonal variation of (a) taxa number and (b) abundance of the main phytoplankton groups in Vela Lake between November 2000 and November 2001.

TSS (0.016-0.081 $\left.\mathrm{g}^{-1}\right)$ were recorded during this period. The most abundant cyanobacteria found in this lake during the study period belonged to the taxa: Aphanizomenon flos-aquae, Chroococcus limneticus, Microcystis aeruginosa and Pseudanabaena sp. (Fig. 2c). The main cyanobacterial blooms were observed at the end of April (dominated by Chroococcus limneticus), mid May (domi- nated by A. flos-aquae) and during June and July (dominated by M. aeruginosa). From the beginning of July until the beginning of September there was a co-dominance of $M$. aeruginosa and C. limneticus (which was the most persistent cyanobacterial taxon during the study period). Pseudanabaena sp. showed also a high density only in the first 15 days of June, co-dominating the bloom with $M$. aeruginosa. In 

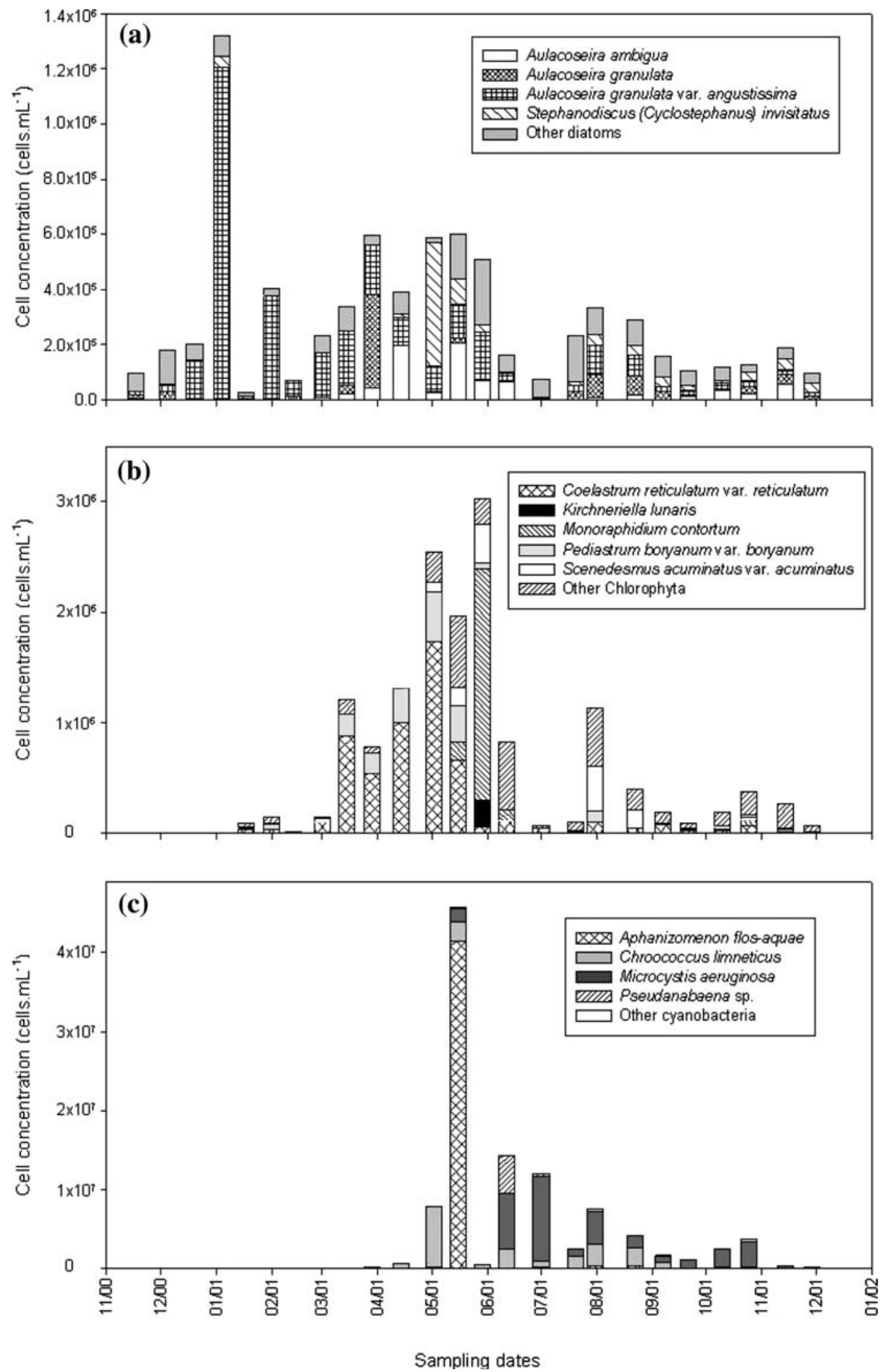

Figure 2. Seasonal dynamics of the most abundant phytoplankton taxa in Vela Lake between November 2000 and November 2001, belonging to the groups: (a) Bacillariophyceae; (b) Chlorophyta and (c) Cyanobacteria. 
spite of the toxic potential during the A.flos-aquae and $M$. aeruginosa blooms, the number of phytoplankton taxa did not show a drastic reduction (Fig. 1a), although the abundance of diatoms and green algae (Fig. 2a and b) decreased markedly during M. aeruginosa bloom in July.

\section{The canonical correspondence analysis}

Results from CCA ordination of most abundant phytoplankton species and environmental variables (Fig. 3a) lead to the conclusion that conductivity, temperature and TSS were strongly correlated $(0.82,-0.75$ and -0.72 , respectively) with the first CCA axis while SRP, dissolved oxygen and TSS were the most correlated $(0.40$, -0.39 and -0.38 , respectively) with the second axis. These two axes alone explained $23 \%$ of the total phytoplankton variance while all the environmental variables considered for the analysis accounted for $55 \%$ of the total variation of the phytoplankton assemblage (Table 3a). On the negative side, the first axis is defined by the green algae Kirchneriella lunaris (KRCH), Scenedesmus semicristatus (SNSM), Scenedesmus spinosus (SNSP), Monoraphidium contortum (MNRC) and Scenedesmus protuberans var. minor (SNPR), but also by the diatom Cyclotella stelligera (CYCS) and the cyanobacteria Microcystis aeruginosa (MIAE). The positive side of the first axis is defined by, among other algae, the diatoms Gomphonema augur (GPAU), Navicula oligotraphenta (NVOL) and Craticula halophila (CRTH). Along the second axis, the positive area is defined by the green algae Scenedesmus serratus (SNSR), Kirchneriella lunaris (KRCH), Pediastrum tetras (PDTT), Lagerheimia subsalsa (LGRH) and Pediastrum simplex var. simplex (PDSS), and the negative extreme is defined by the diatoms Cyclotella stelligera (CYCS) and Gomphonema augur (GPAU), the chlorophyte Botryococcus braunii (BTRB) and the cyanobacteria Oscillatoria sp. (OSCL). The distance of $K$. lunaris (KRCH) (Fig. 3a) from the other species suggests it occurs only during certain conditions possibly related to growth under adverse conditions such as oxygen depletion.

A second CCA (Table 3c and Fig. 3b) is shown including the $A$. flos-aquae and the M. aeruginosa densities as 'explanatory' variables. The ordination diagram obtained (Fig. 3b) shows that conductivity and temperature are still strongly correlated ( -0.81 and 0.74 , respectively) with the first CCA axis, but immediately followed by $M$. aeruginosa abundance and TSS with correlations of 0.65 and 0.60 , respectively, with this same first axis. The second axis shows correlation with SRP and nitrate concentrations (both with 0.44). Aphanizomenon flos-aquae abundance is weakly correlated with both the first and second axes $(0.03$ and 0.06 , respectively), indicating its low influence over the phytoplankton assemblage. The phytoplankton (without $A$. flos-aquae and M. aeruginosa) variance explained by the used total assemblage of explanatory variables was $61 \%$ while the first two axes still explain $23 \%$ of the total phytoplankton variance. This analysis was preceded by a CCA (Table $3 b$ ) using the same species data (without the $A$. flos-aquae and the $M$. aeruginosa abundances) but against only the physico-chemical parameters used in the first CCA (Fig. 3a and Table 3a). This CCA (Table $3 b$ ) showed that the first axis was highly correlated with conductivity $(-0.81)$ and temperature $(0.74)$ while the second axis was related to SRP (0.48) and TSS (0.46). The two axes explained $22 \%$ of the total variance while the CCA explained $54 \%$. Therefore, the cyanobacterial blooms occurrence (of $M$. aeruginosa, in particular) raised the explained variance of the phytoplanktonic assemblage during that year by almost $7 \%$ once the cyanobacterial densities of A. flos-aquae and $M$. aeruginosa were the factors missing in the first CCA and included in the second CCA (considering the same phytoplankton assemblage).

\section{Discussion}

There is a lack of recently published information concerning planktonic dynamics in Mediterranean

Figure 3. Results from canonical correspondence analysis for Vela Lake between November 2000 and November 2001: (a) Triplot for sampling dates, most abundant phytoplankton species and environmental variables; (b) Triplot for sampling dates, most abundant phytoplankton species (excluding A. flos-aquae and M. aeruginosa) and environmental variables plus $A$. flos-aquae and $M$. aeruginosa densities. 


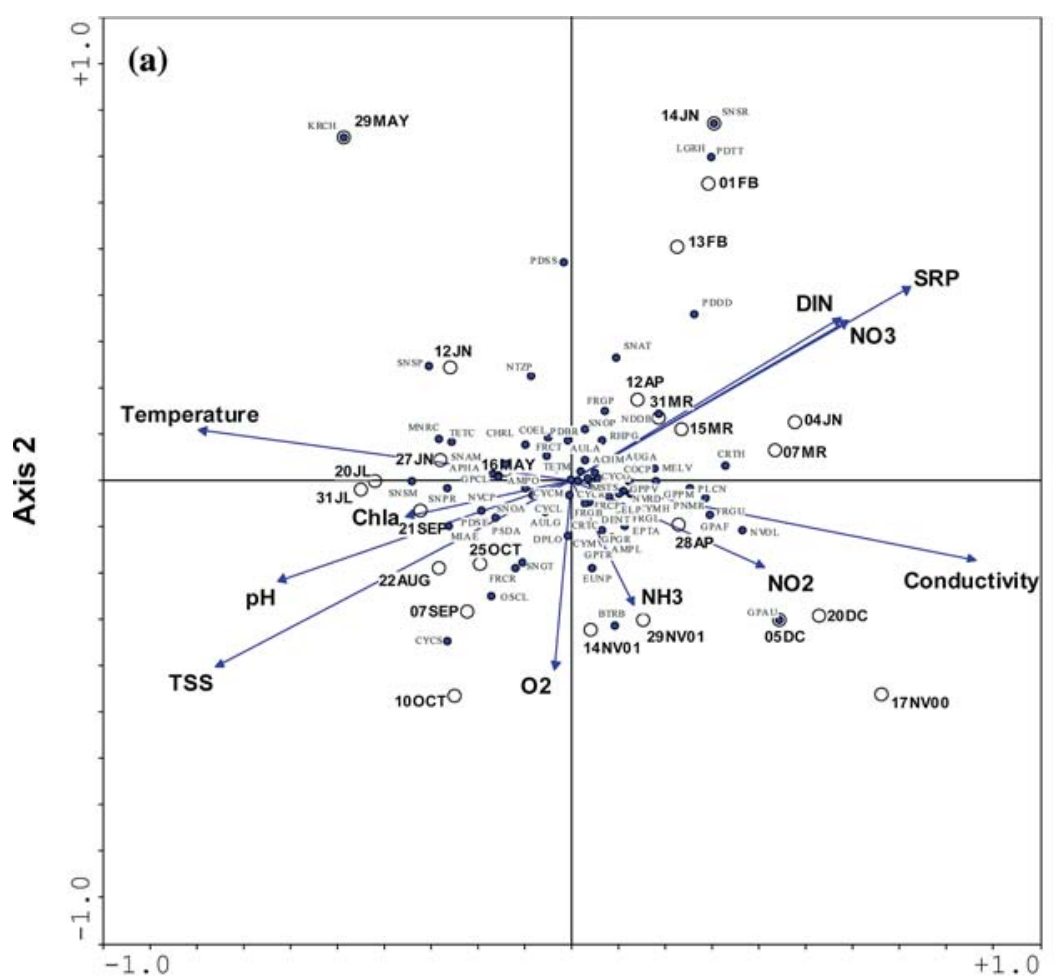

Axis 1

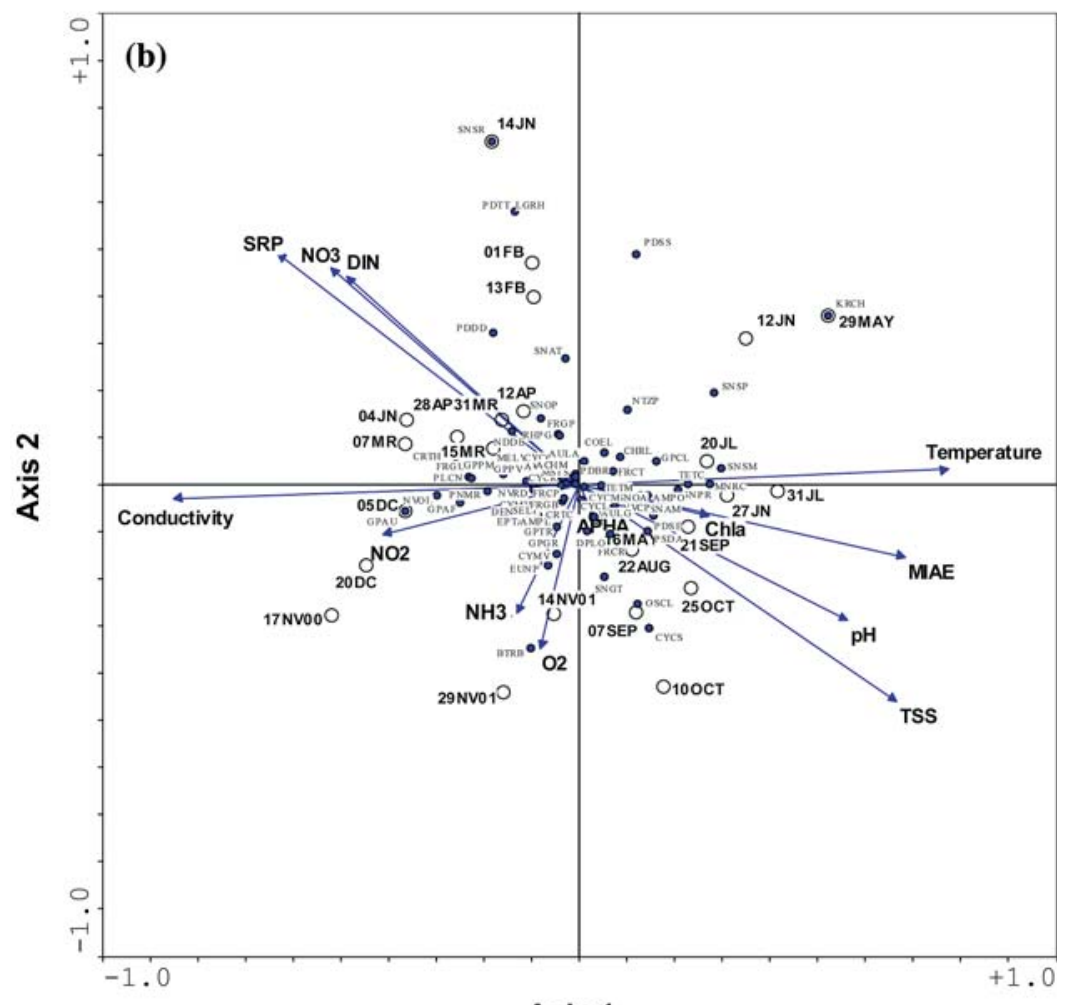

Axis 1 
Table 3. (a) Summary of canonical correspondence analysis between most abundant phytoplankton species and physico-chemical parameters; (b) Summary of CCA analysis between most abundant phytoplankton species (without A. flos-aquae and M. aeruginosa) and physico-chemical parameters; (c) Summary of CCA analysis between most abundant phytoplankton species (without $A$. flos-aquae and $M$. aeruginosa) and physico-chemical parameters (plus $A$. flos-aquae and $M$. aeruginosa densities as explanatory variables). The study period was from November 2000 to November 2001 in Vela Lake

\begin{tabular}{|c|c|c|c|c|c|c|}
\hline & \multicolumn{2}{|l|}{ (a) } & \multicolumn{2}{|l|}{ (b) } & \multicolumn{2}{|l|}{ (c) } \\
\hline & Axis 1 & Axis 2 & Axis 1 & Axis 2 & Axis 1 & Axis 2 \\
\hline Eigenvalues & 0.158 & 0.115 & 0.145 & 0.114 & 0.149 & 0.119 \\
\hline Species-environment correlations & 0.946 & 0.954 & 0.943 & 0.949 & 0.951 & 0.957 \\
\hline \multicolumn{7}{|l|}{ Cumulative percentage variance } \\
\hline Of species data & 13.3 & 22.9 & 12.4 & 22.1 & 12.7 & 22.9 \\
\hline Of species-environment relation & 24.0 & 41.4 & 22.8 & 40.7 & 20.8 & 37.5 \\
\hline Sum of all unconstrained eigenvalues & 1.190 & & 1.172 & & 1.172 & \\
\hline Sum of all canonical eigenvalues & 0.659 & & 0.637 & & 0.715 & \\
\hline Variance explained by the CCA & $55.4 \%$ & & $54.4 \%$ & & $61.0 \%$ & \\
\hline Variance explained by the first two axes & $22.9 \%$ & & $22.1 \%$ & & $22.9 \%$ & \\
\hline
\end{tabular}

lakes, especially in Portuguese territory where there is a strong climatic influence from the Atlantic Ocean. For Vela Lake (Antunes et al., 2003) there is not sufficient information for recent years to allow detailed comparative analysis of physico-chemical and phytoplankton data. Other studies (e.g., Dokulil \& Teubner, 2000; Eynard et al., 2000; Mischke, 2003) have observed phytoplankton seasonal succession in lakes where diatoms dominate under conditions of low temperatures and high levels of nutrients and cyanobacterial dominance coincides with the highest temperatures and lowest nutrient concentrations. This is probably due to the ability of some cyanobacteria to fix $\mathrm{N}$, storing $\mathrm{P}$ and regulate their buoyancy (Dokulil \& Teubner, 2000; Oliver \& Ganf, 2000). However, in general, low $\mathrm{N}: \mathrm{P}$ ratio levels enhance bloom occurrence in cyanobacteria (Jacoby et al., 2000). In the present work, a similar seasonal phytoplankton community succession was found for Vela Lake during the study period. The multivariate analysis results indicate that phytoplankton assemblage was highly correlated with conductivity and temperature, but also by TSS and nutrient concentrations (particularly phosphorus). Generally, in winter and autumn months (high nutrient levels and conductivity, along with low temperature and TSS values) diatoms dominated the phytoplankton community. Chlorophytes dominated in early spring and cyanobacteria from early spring until the beginning of autumn (low nutrient levels and conductivity, along with high temperature and TSS values).

The development of the dense A. flos-aquae bloom was preceded by the lowest concentrations of nitrogen, indicating that this cyanobacterial strain is not very dependent on nitrogen availability, probably due to its $\mathrm{N}$-fixing capability (Oliver \& Ganf, 2000). However, the availability of phosphate appeared to be required for the bloom development. Under P depletion, the A. flos-aquae occurred in low densities after the end of May, suggesting that this strain is not able to dominate in phosphate depleted conditions. This phosphorus dependence has been reported for this species (Teubner et al., 1999; Dokulil \& Teubner, 2000; de Figueiredo et al., 2004b). On the other hand, M. aeruginosa blooms occurred after the dissolved oxygen depletion and the sudden increase of the ammonium levels. The $M$. aeruginosa density remained relatively high until the end of October 2001, even with phosphate depletion in the water. This is most likely due to its ability to store phosphorus and exist in the presence of depleted ambient phosphorus levels (Dokulil \& Teubner, 2000) although it requires ambient sources of nitrogen (Jacoby et al., 2000; Oliver \& Ganf, 2000).

In the phytoplankton community, at the time of the cyanobacterial blooms, there was a severe reduction in the chlorophyll $a$ concentration. 
Nevertheless, the number of the phytoplanktonic taxa was near the maximal, with development of Bacillariophyceae and particularly Chlorophyceae species such as Kirchneriella lunaris that were not particularly prevalent over the remainder of the year. Phytoplankton community dynamics during a cyanobacterial bloom may give important information about the noxious potential of the bloom due to allelopathy (Kearns \& Hunter, 2001; Singh et al., 2001; Suikkanen et al., 2004) and/or competitive advantage of cyanobacteria over microalgae (Oliver \& Ganf, 2000). Aphanizomenon flos-aquae strains isolated from blooms in Portuguese water bodies (including lakes) are known to produce toxins, namely PSP-type toxins (Vasconcelos, 1999; Pereira et al., 2000; Ferreira et al., 2001; Vasconcelos, 2001) and more than 40 Microcystis aeruginosa strains isolated from Vela Lake have been reported as toxic by Vasconcelos et al. (1993), with production of microcystins. Using a multivariate analysis with the bloomcausing cyanobacteria as explanatory variables we found that particularly $M$. aeruginosa abundance had an important influence on the phytoplankton assemblage in general with a negative correlation with the diatom and chlorophyte abundance which may be explained by the competitive advantage of this cyanobacteria over the other phytoplankton in the lake due to the abilities such as regulation of buoyancy and phosphorus storage (Jacoby et al., 2000; Oliver \& Ganf, 2000) and/or the allellopatic potential already described for this cyanobacteria in laboratory studies (Singh et al., 2001). Nevertheless, further work on toxin production of strains and the effects on algae is required.

The idea that cyanobacteria may work as an important modulator (along with the environmental parameters) in the composition of phytoplankton community may be very significant when discussing the phytoplankton seasonal dynamics in a water body that suffers from potentially toxic cyanobacterial blooms. Moreover, cyanobacterial dominance may also change the cladoceran community since the toxicity of cyanobacteria such as $M$. aeruginosa towards cladocerans is well known (Ferrão-Filho \& Azevedo, 2003) and M. aeruginosa blooms in Vela Lake have been recorded to be toxic (Vasconcelos et al., 1993). Thus, in future work, the presence of cyanotoxins must be assessed along with allelopathic tests using the bloom-forming cyanobacteria in order to gain a better understanding of the phytoplankton community dynamics. From a public health point of view and considering that $A$. flos-aquae and $M$. aeruginosa are potentially toxic, chlorophyll $a$ concentrations recorded during the blooms in May and late June corresponded to a moderate to high risk for human health (WHO, 2003) which emphasizes also the need for cyanotoxins analysis in this lake.

\section{Conclusions}

In May 2001, Vela Lake suffered an intense $A$. flosaquae bloom and, in June 2001, M. aeruginosa blooms occurred. The development of the A. flosaquae bloom was related to the lowest nitrogen levels recorded in the lake and the $M$. aeruginosa bloom development was associated with high ammonium levels and phosphate depletion. These blooms pose potential health risks, by having chlorophyll $a$ concentrations above the limit, according to the World Health Organization (WHO, 2003). Conductivity and temperature, followed by the total suspended solids and nutrient concentrations, have shown to be the parameters with the highest correlation with the phytoplankton assemblage in Vela Lake during the study period. Nevertheless, the occurrence of a cyanobacterial bloom (mainly of Microcystis aeruginosa) proved to be also an important parameter correlated with the phytoplankton assemblage during that time. This may be due to the cyanobacterial competitive advantage over algae but also to the toxicity of the bloom-forming cyanobacteria (such as Aphanizomenon flos-aquae and Microcystis aeruginosa which have toxic strains occurring in Portuguese freshwaters, namely in Vela Lake). Future investigation to monitor for the presence of cyanotoxins should be carried out along with allelopathic tests using the bloom-forming cyanobacteria and several algae from different groups to find which algae are more sensitive to cyanobacteria. If a direct relation between phytoplankton assemblage dynamics, environmental parameters and cyanotoxin production could be established, it could be a useful mechanism to help understand, predict and prevent the development of cyanobacterial blooms (through control of nutrient inputs, for example). 


\section{References}

Antunes, S. C., N. Abrantes \& F. Gonçalves, 2003. Seasonal variation of the abiotic parameters and the cladoceran assemblage of Lake Vela: comparison with previous studies. Annales de Limnologie, International Journal of Limnology 39: 255-264.

APHA, 1992. Standard Methods for the Examination of Water and Wastewater (18th edn.), American Public Health Association, Washington, DC.

Chellappa, N. T. \& M. A. Costa, 2003. Dominant and coexisting species of cyanobacteria from an eutrophicated reservoir of Rio Grande do Norte State, Brazil. Acta Oecologica 24: S3-S10.

Chorus, I. \& J. Bartram (eds), 1999. Toxic Cyanobacteria in Water: A Guide to Their Public Health Consequences, Monitoring and management. E\&FN Spon, London.

Codd, G. A., 2000. Cyanobacterial toxins, the perception of water quality, and the priorisation of eutrophication control. Ecological Engineering 16: 51-60.

de Figueiredo, D. R., U. M. Azeiteiro, S. M. Esteves, F. J. M. Gonçalves \& M. J. Pereira, 2004a. Microcystin producing blooms - a serious global public health issue. Ecotoxicology and Environmental Safety 59: 151-163.

de Figueiredo, D. R., U. M. Azeiteiro, F. J. M. Gonçalves \& M. J. Pereira, 2004b. Aphanizomenon flos-aquae grown under different nutrient concentrations and its effects over two green algae. Fresenius Environmental Bulletin 13: 657-664.

de Figueiredo, D. R., S. C. Antunes, M. J. Pereira \& F. J. M. Gonçalves, 2004c. Chronic effects of Aphanizomenon flosaquae on the survival and reproduction of dapnhids. Fresenius Environmental Bulletin 13: 665-670.

Dokulil, M. T. \& K. Teubner, 2000. Cyanobacterial dominance in lakes. Hydrobiologia 438: 1-12.

Eynard, F., K. Mez \& J. -L. Walther, 2000. Risk of cyanobacterial toxins in Riga waters. Water Research 34: 29792988.

Ferrão-Filho, A. S. \& S. M. F. O. Azevedo, 2003. Effects of unicellular and colonial forms of toxic Microcystis aeruginosa from laboratory cultures and natural populations on tropical cladocerans. Aquatic Ecology 37: 23-35.

Ferreira, F. M. B., J. M. F. Soler, M. L. Fidalgo \& P. Fernández-Vila, 2001. PSP toxins from Aphanizomenon flos-aquae (cyanobacteria) collected in the Crestuma-Lever reservoir (Douro river, northern Portugal). Toxicon 39: 757-761.

Geitler, L., 1932. Cyanophyceae. In Rabenhorst's, L. (ed.), Kryptogamen-Flora von Deutschland, Österreich und der Schweiz, band 14. Akademische Verlagsgesellschaft, Leipzig.

Germain, H., 1981. Flore des diatomées. Diatomophycées d'eaux douces et saumâtres du Massif Armoricain et des contrées voisines de l'Europe occidentale. Boubée Éditions, Paris.

Jacoby, J. M., D. C. Collier, E. B. Welch, F. J. Hardy \& M. Crayton, 2000. Environmental factors associated with a toxic bloom of Microcystis aeruginosa. Canadian Journal of Fisheries and Aquatic Sciences 57: 231-240.

Kearns, K. D. \& M. D. Hunter, 2001. Toxin-producing Anabaena flos-aquae induces settling of Chlamydomonas rein- hardtii, a competing motile alga. Microbial Ecology 42: 8086.

Komárek, J. \& K. Anagnostidis, 1989. Modern approach to the classification system of cyanophytes -4 - Nostocales. Archives of Hydrobiology (Supplement 82): 247-345.

Komárek, J. \& K. Anagnostidis, 1999. Cyanoprokariota - 1. Teil Choococcales. In Ettl, H., G. Gärtner, H. Heynig \& D. Mollenhauer (eds), Süßwasserflora von Mitteleuropa, Band 19/1. G. Fischer Verlag, Jena, Stuttgart, Lübeck, Ulm.

Komárek, J. \& B. Fott, 1983. Das Phytoplankton des Süsswassers, Systematik und Biologie. 7. Teil, 1. Hälfte, Chlorophyceae (Grünalgen). Ordnung: Chlorococcales. Scweizerbart'sche Verlagsbuchhandlung, Stuttgart.

Krammer, K. \& H. Lange-Bertalot, 1986-1991. Bacillariophyceae. In Ettl, H., G. Gärtner, H. Heynig \& D. Mollenhauer (eds), Süßwasserflora von Mitteleuropa, Vol. 2. G. Fischer Verlag, Stuttgart.

Lange-Bertalot, H., 2001. Navicula sensu stricto, 10 genera separated from Navicula sensu stricto, Frustulia. In LangeBertalot, H. (ed.), Diatoms of Europe. Diatoms of the European Inland Waters and Comparable Habitats, Vol. 2. A.R.G. Gantner Verlag K.G, Ruggell.

Lind, O. T., 1979. Handbook of Common Methods in Limnology (2nd edn.), C.V. Mosby Company, St. Louis.

Lotocka, M., 2001. Toxic effect of cyanobacterial blooms on the grazing activity of Daphnia magna Straus. Oceanologia 43(4): 441-453.

Lund, J. W. G., C. Kipling \& E. D. Le Cren, 1958. The inverted microscope method of estimating algal numbers and the statistical basis of estimations by couting. Hydrobiologia 11: 143-170.

Mischke, U., 2003. Cyanobacteria associations in shallow polytrophic lakes: influence of environmental factors. Acta Oecologica 24: S11-S23.

Oliver, R. L. \& G. G. Ganf, 2000. Freshwater blooms. In Whitton, B. A. \& M. Potts (eds), The Ecology of Cyanobacteria. Kluwer Academic Publishers: 149-194.

Pouria, S., A. de Andrade, J. Barbosa, R. L. Cavalcanti, V. T. S. Barreto, C. J. Ward, W. Preiser, G. K. Poon, G. H. Neild $\&$ G. A. Codd, 1998. Fatal microcystin intoxication in haemodialysis unit in Caruaru, Brazil. The Lancet 352: 21-26.

Pereira, P., H. Onodera, D. Andrinolo, S. Franca, F. Araújo, N. Lagos \& Y. Oshima, 2000. Paralytic shellfish toxins in the freshwater cyanobacterium Aphanizomenon flos-aquae, isolated from Montargil reservoir, Portugal. Toxicon 38(12): 1689-1702.

Silva, P. C. L. D., F. Gonçalves, R. Ribeiro \& A. M. V. M. Soares, 1997. First evaluation of the restoration of Braças Lagoon (Figueira da Foz - Portugal). Archives of Hydrobiology 141: 109-125.

Singh, D. P., M. B. Tyagi, A. Kumar, J. K. Thakur \& A. Kumar, 2001. Antialgal activity of a hepatotoxin-producing cyanobacterium, Microcystis aeruginosa. World Journal of Microbiology, Biotechnology 17: 15-22.

Suikkanen, S., G. O. Fistarol \& E. Granéli, 2004. Allelopathic effects of the Baltic cyanobacteria Nodularia spumigena, Aphanizomenon flos-aquae and Anabaena lemmermannii on algal monocultures. Journal of Experimental Marine Biology and Ecology 308: 85-101. 
ter Braak, C. J. F., 1986. Canonical correspondence analysis: a new eigenvector technique for multivariate direct gradient analysis. Ecology 67: 1167-1179.

ter Braak, C. J. F., 1995. Ordination. In Jongman, R. H. G. (ed.), Data Analysis in Community and Landscape Ecology. Cambridge University Press, Cambridge: 91-173.

Teubner, K., R. Feyerabend, M. Henning, A. Nicklisch, P. Woitke \& J. -G. Kohl, 1999. Alternative blooming of Aphanizomenon flos-aquae or Planktothrix agardhii induced by the timing of the critical nitrogen:phosphorus ratio in hypertrophic riverine lakes. Archives of Hydrobiology, Special Issues of Advanced Limnology 54: 325-344.

Vasconcelos, V. M., 1999. Cyanobacteria toxins in Portugal: effects on aquatic animals and risk for human health.
Brazilian Journal of Medical and Biological Research 32: 249-254.

Vasconcelos, V. M., 2001. Freshwater cyanobacteria and their toxins in Portugal. In Chorus, I. (ed.), Cyanotoxins Occurrence, Causes, Consequences. Springer, Berlin: 6267.

Vasconcelos, V. M., T. Campos, A. Amorim \& A. M. V. M. Soares, 1993. Toxicidade de estirpes de cianobactérias isoladas a partir das lagoas das Braça, Vela e Mira. Bol. UCA U Algarve UCTRA 1: 193-201.

WHO, 2003. Algae and cyanobacteria in fresh water. In: Guidelines for Safe Recreational Water Environments. Vol. I: Coastal and Fresh Waters. World Health Organization, Geneva, 136-158. 